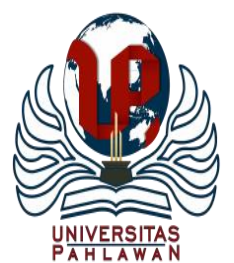

Edukatif : Jurnal Ilmu Pendidikan Volume 3 Nomor 4 Tahun 2021 Halm 2081 - 2091

EDUKATIF: JURNAL ILMU PENDIDIKAN

Research \& Learning in Education

https://edukatif.org/index.php/edukatif/index

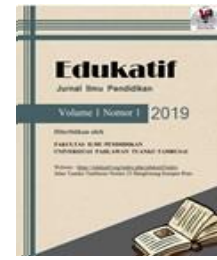

\title{
Students' Perspectives towards English Short Movies as Media to Assist Their Vocabulary Mastery in Online Learning
}

\author{
Irvan Irmanda $^{1 凶}$, Yousef Bani Ahmad ${ }^{2}$, Abdul Kodir Al Baekani ${ }^{3}$ \\ Universitas Singaperbangsa Karawang, Indonesia ${ }^{1,2,3}$ \\ E-mail : irvanirmanda123@ gmail.com ${ }^{1}$, yousef.baniahmad@fkip.unsika.ac.id ${ }^{2}$, \\ akodir.albaekani@staff.unsika.ac.id ${ }^{3}$
}

\begin{abstract}
Abstrak
Penelitian ini membahas tentang perspektif siswa tentang movie pendek bahasa Inggris sebagai media untuk membantu penguasaan kosakata mereka dalam pembelajaran online. Penelitian ini menggunakan inkuiri naratif. Tujuan dari penelitian ini adalah untuk mengidentifikasi perspektif siswa tentang penggunaan movie pendek bahasa Inggris sebagai media untuk membantu penguasaan kosakata mereka dalam pembelajaran online. Penelitian ini dilakukan dengan 3 partisipan di kelas 11, dengan rata-rata usia 16-17 tahun pada tahun ajaran 2020-2021. Peserta berasal dari SMAN 2 Telukjambe Timur, Karawang dimana mereka diberikan wawancara terkait movie pendek untuk membantu penguasaan kosakata mereka. Dalam penelitian ini siswa pernah mengalami atau pernah melakukan proses pembelajaran dengan menggunakan movie pendek. Dalam pengumpulan data, penelitian ini menggunakan wawancara dan dokumentasi virtual melalui aplikasi Zoom. Selanjutnya peserta di SMAN 2 Telukjambe Timur adalah siswa yang bersedia mengikuti penelitian ini. Teknik yang digunakan dalam analisis data mengacu pada Braun dan Clark (2006) dengan meliputi 6 aspek analisis. Selain itu, temuan ini dibagi menjadi 6 aspek, meliputi (1) Alasan, (2) Afektif, (3) Metode, (4) Jenis kelas kata, (5) Jenis movie, (6) Kelebihan dan kekurangan.
\end{abstract}

Kata Kunci: Film Pendek Bahasa Inggris, Narrative Inquiry, Pengajaran Kosakata.

\begin{abstract}
This study is about students' perspectives on English short movies as media to assist their vocabulary mastery in online learning. This research uses narrative inquiry. The purpose of this study was to identify students perspectives of the use of English short movies as media to assist their vocabulary mastery in online learning. This research is conducted with 3 participants in grade 11, with an average age of 16-17 years in the 20202021 school years. Participants were from SMAN 2 Telukjambe Timur, Karawang where they were given interviews related to short movies to help their vocabulary mastery. In this study, students have experienced or have carried out the learning process using short movies. In collecting data, this research uses interviews and virtual documentation through Zoom application. Furthermore, the participants at SMAN 2 Telukjambe Timur were students who were willing to take part in this study. The technique used in data analysis refers to Braun and Clark (2006) by covering 6 aspects of the analysis. In addition, this finding is divided into 6 aspects, including (1) Reasons, (2) Affective, (3) Methods, (4) Kinds of word class, (5) Kinds of movies, (6) Advantages and Disadvantages.
\end{abstract}

Keywords: English Short Movie, Narrative Inquiry, Teaching Vocabulary.

Copyright (c) 2021 Irvan Irmanda, Yousef Bani Ahmad, Abdul Kodir Al-Baekani

$\triangle$ Corresponding author:

Email : irvanirmanda123@gmail.com

DOI $\quad$ : https://doi.org/10.31004/edukatif.v3i4.1151

ISSN 2656-8063 (Media Cetak)

ISSN 2656-8071 (Media Online)

Edukatif : Jurnal Ilmu Pendidikan Vol 3 No 4 Tahun 2021 p-ISSN 2656-8063 e-ISSN 2656-8071 
2082 Students' Perspectives towards English Short Movies as Media to Assist Their Vocabulary Mastery in Online Learning - Irvan Irmanda, Yousef Bani Ahmad, Abdul Kodir Al-Baekani

DOI: https://doi.org/10.31004/edukatif.v3i4.1151

\section{INTRODUCTION}

The language has some elements, such as grammar and vocabulary. One of the most important language items that should be taught to children is vocabulary (Patahuddin et al., 2017). As stated by (Aditama \& Solikhah, 2018) Recognizing enough vocabulary can make the students able to communicate and know English at least in a simple way because is the core of English. Language learning deals with learning vocabulary. It is basic to communicate and also important for the acquisition process. It means that learning a language be separated from learning vocabulary. It is important to introduce it as a basic step to children in order to help them to understand utterances and to prepare them to learn English next level.

(Wafi, 2013) defines a vocabulary as a total number of words that (with rules combining them) make up a language. Longman Dictionary of Contemporary English writes the definition of vocabulary "as a list of words". Usually in alphabetical order and with explanation, their meanings are less complete than a dictionary. From the above definition of vocabulary, it can be concluded that vocabulary is a word, phrase idiom, or expression that is known, learned, and used by a person in daily life for communication.

Vocabulary is a very basic aspect of communication. According to the English curriculum, learning English language consists of four skills those are: reading, listening, speaking, and writing. In addition, structures, vocabulary, pronunciation, and spelling are as the component of English. Therefore, vocabulary is one of the important language elements that the students should master (Lail, 2019).

Mastering a good vocabulary is one of the most important things for a language speaker to be able to communicate with other people. Without adequate vocabulary or mastery of words, it is difficult for anyone to use the four language skills, listening, speaking, reading, and writing. In the process of learning English, students must be able to increase their vocabulary in order to communicate effectively. Without extensive vocabulary, learners often achieve less than their potential and maybe discouraged from making use of language". Furthermore, the students with poor vocabulary master can't be able to communicate their ideas clearly, and they-likely unable to comprehend any texts written in English such as newspapers or magazines, and even they likely fail to understand the news on radio or television.

Back in the late 1970s, the attention to vocabulary learning has been attracted scholars to be studied. It was begun by a very famous British linguist, David Wilkins in 1972. David Arthur Williams (Lin et al., 2013) stated, "Without grammar, very little can be conveyed, but without vocabulary, nothing can be conveyed." Moreover, the better communication of EFL learners depends on how more vocabulary they have (Sarani, A., \& Shirzaei, 2016); (bin Tahir, 2012) This indicates that mastering the vocabulary is a must to bridge the use of the English (Ivone, 2005) either the building of a sentence or conversation. The way of communication through English, of course, reflects whether someone could actually speak English or only a little English.

Vocabulary mastery is indeed important, however, the lecture and game methods of teaching vocabulary used by the teacher make students lazy to learning vocabulary. Therefore, the students easily got bored, more passive, and worried to learn English. English teachers only used textbooks and whiteboards in the teaching-learning process. The students differ greatly in the skills they use in learning strategies. Therefore, the teacher needs to make new teaching training especially in the strategy of vocabulary development. With those strategies, students are expected to easily understand the context of learning vocabulary (Sarani, A., \& Shirzaei, 2016).

To make it easier for students in learning English, the teacher often uses media as one strategy to assist students' motivation. There are a lot of enjoyable media that the teachers can use to teach vocabulary to the students. One of the strategies will be used by the researcher is teaching English using movie. The movie is considered as one of the media of learning English because movies can make students interested and motivated in learning (Etemadi, 2012). The movie is one of the audio-visual aids. The movie is a series of still or moving images. It is produced by recording photographic images with cameras, or by creating images using 
2083 Students' Perspectives towards English Short Movies as Media to Assist Their Vocabulary Mastery in Online Learning - Irvan Irmanda, Yousef Bani Ahmad, Abdul Kodir Al-Baekani

DOI: https://doi.org/10.31004/edukatif.v3i4.1151

animation techniques or visual effects. In addition, learners will hear many words and phrases, especially idioms and colloquial expressions (Lestari, 2016).

Moreover, the movie is one of the authentic media that can be used to engage students in vocabulary learning. (Kabooha, 2016) stated that movies can be considered as authentic material and they provide the learners with indigenous input. The genuine input helps the student to understand as there is a connection between the more traditional learning-teaching classrooms. Moreover, as Krashen 1985, cited (Aditama \& Solikhah, 2018) points out that a natural input helps the learners to acquire language without necessarily even noticing that they are hearing or reading a foreign language. Furthermore, said that vocabulary learning is an important aspect of learning a foreign language. The student was improved much if they learn more words and expressions.

In addition, the integration of short movies in the EFL class can also improve students' abilities, especially in vocabulary mastery (Baratta, A., \& Jones, 2008). (Khan, 2015) believes that short movies "visuality" can facilitate understanding for language learners in an ideal visual context, which makes them an effective language teaching tool, and considers that short movies offer a variety of methods and resources for teaching the target language, helping students to improve their communication skills. Many researchers have examined the effectiveness of using short movies in improving student vocabulary. (Lestari, 2016)in his research entitled the use of English subtitles in movies to improve students' vocabulary, found that the use of English subtitles proves that students find it easier to get information in movies and also they know some new words from the movie.

Moreover, research conducted by (Lail, 2019) found that students' ability to learn vocabulary through the application of movie media with subtitles increased, but there was no certainty regarding students' perspectives on the use of English short movies that helped students to increase their vocabulary. Short movies can indeed help students' vocabulary mastery. However, the extent of knowledge about students' perspectives on the use of short movies still needs to be investigated to realize the need for further research that presents triangulation of the use of students' perspective data on this particular topic, the researcher aims to conduct a narrative inquiry study entitled Student Perspectives towards English short movies as media to assist their vocabulary mastery in online learning.

\section{METHOD}

The design used in this research is narrative inquiry. Narrative inquiry is a study that involves a collection of stories by generating and documenting these narratives and interpreting them in terms of the literature of a field and the process of its implications for participants. In addition, this study uses a qualitative approach to provide an in-depth analysis of the resulting data. This means that the research design related to this study aims to find out more about students' perspectives on English short movies as a medium to help their vocabulary mastery in online learning.

This research was conducted on 3 participants including grade 11 students in even semesters who are 16-17 years old on average in the 2020-2021 school years. The participants came from SMAN 2 Telukjambe Timur Karawang where the three participants had experience learning vocabulary using English short movie media. Furthermore, the researcher provides an explanation of the course of the research to students who are ready to take part in this research without any coercion from the researcher. For the main data collection, the researcher used personal interviews.

Personal interviews focused on individual students, meaning that the researcher interviewed each participant at different times. The researcher also decided to interview each participant at different times to gain efficiency in obtaining information due to the flexibility of the long time. The language used in the interview is Indonesian. In this case, the interview session was conducted through the Zoom application because of the Covid-19 pandemic protocol where researchers are not allowed to conduct direct or face-to- 
2084 Students' Perspectives towards English Short Movies as Media to Assist Their Vocabulary Mastery in Online Learning - Irvan Irmanda, Yousef Bani Ahmad, Abdul Kodir Al-Baekani

DOI: https://doi.org/10.31004/edukatif.v3i4.1151

face interviews with participants for health safety. To conduct interviews, the researcher allocated 30 minutes of interview time for each participant. At this stage, the researcher uses a voice recorder or screen recording to obtain interview information, and notes to highlight some important points from the discussions. The interviews focused on students' perspectives on English short movies as a medium to help their vocabulary mastery in online learning. In addition, This qualitative data was analyzed by researchers using techniques (Braun, V., \& Clarke, 2006). According to Braun and Clarke (2006), there are six steps to conducting a thematic analysis. Each step is explained besides (1) Familiarizing yourself with the data, (2) Generating initial codes, (3) Searching for themes, (4) Reviewing the theme, (5) Defining and Naming themes, and (6) Reporting the Outcomes.

\section{RESULT AND DISCUSSION}

The purpose of this research is to find out students' perspectives towards English short movies as media to assist their vocabulary mastery in online learning. The findings of this subsection are taken from students' answers in the interview process. Each subsection of this perspective is presented in six points or categorizations, including (1) the reasons students learn about vocabulary using short movies in English, (2) effective in learning vocabulary using short movies, (3) methods in learning vocabulary, (4) what kinds of word class are used, (5) what kinds of movies are used, and (6) the advantages and disadvantages of learning vocabulary using English short movies.

\section{The Reasons Students Learn Vocabulary Using Short Movies in English}

In learning vocabulary, there are at least several factors or reasons that encourage students to master vocabulary so that they can increase their skills in English. From the interviews, two of the three participants stated that the movie is an audio visual that makes students interested in learning vocabulary and is more interesting than learning manually using a book or dictionary. As the following representative quote illustrates:

"The thing is that I prefer visuals, so in videos/movies, the visuals are really visible, apart from being able to see the movements of the characters' activities, we can also learn directly so we understand that, that's more or less the case."(DSY-p2)

As we can see from the quote above, one of the students has a relevant reason because short movies have audio visuals that can attract students to watch the movies they like. In addition, students can learn from the gestures and pronunciation of the movie's characters. In addition, one of the students (YLD-p3) revealed that watching movies is one of the media that makes it more fun than studying in books. This finding is illustrated by YLD's following answer:

"Because it's more fun than studying in a book or on the internet because it's a movie that many people definitely like and I'm also one of those people who like movies" (YLD-p3)

Apparently, from the answers above, the students have expressed positive perspectives. Therefore, we can conclude that the two participants have represented that their reasons and factors are because short movies are one of the media that many students like because of its visuals and have an interest in being watched by students and students prefer watching movies while learning vocabulary rather than studying use a dictionary or book.

\section{Affective In Learning Vocabulary Using Short Movies}

From the interview transcript data, the findings show that there is an affective domain in learning vocabulary that has been described in the interview transcript data with three participants, which includes students' enthusiasm, impressions, and feelings in learning vocabulary using English short movies. We can see from the enthusiasm of students in watching short movies, two out of three participants have the same answer 
2085 Students' Perspectives towards English Short Movies as Media to Assist Their Vocabulary Mastery in Online Learning - Irvan Irmanda, Yousef Bani Ahmad, Abdul Kodir Al-Baekani

DOI: https://doi.org/10.31004/edukatif.v3i4.1151

in terms of enthusiasm. The first participant (NZL) and the third participant (YLD) had a positive response to the enthusiasm in watching English short movies as media to help master vocabulary. While the second participant (DSY) was less enthusiastic but enjoyed the movie. As the following quote illustrates:

"Very enthusiastic because I think English is a unique language and is an international language, right? Who doesn't want to learn English, people know that language is important" (NZL-p1).

"Quite enthusiastic because what I have said is that the movie must have a lot of genres and it's fun to watch especially while watching while learning too" (YLD-p3).

From the illustration above, it can be seen that two participants have a positive perspective with reasons that are relevant to their answers. The first participant revealed that English is a unique and international language. While the third participant revealed that movies have many genres. Therefore, students enthusiastically use English short movies as a media for learning vocabulary with relevant reasons. On the other hand, the third participant had a different opinion. As illustrated below:

"If you're enthusiastic, it's not too much, just because enjoy the movies, it brings the atmosphere with you so we can all learn that too" (DSY-p2).

As stated above, that the third participant was less enthusiastic but he just enjoyed the movie. On the other hand, in terms of feelings and impressions, all participants had positive perspectives in using English short movies as a media to help them learn vocabulary. From the three participants revealed that learning to use movies was not boring and not as complicated as imagined, instead they were able to understand and pay attention to the pronunciation of the characters from the movie which were interesting and fun to watch. As illustrated below:

“...I thought it would be boring and uninteresting, but it's not, because in short movies, all the characters often interact with dialogues in various backgrounds and with various topics so that the contents can be remembered easily and to help the audience understand the conversations that are going on talked about". (NZL-p1)

"It looks like it's really fun, it turns out that in the movie the characters are talking, and the pronunciation is also clear, so if we just read it in the dictionary". (DSY-p2)

"My impression is yes, it turns out that learning vocabulary through short movies is not as complicated as I thought, because if you study at school, the material is like that, if the movie is more interesting and more fun". (YLD-p3)

From the three statements expressed by the three participants above, it showed a positive response from the participants. In addition, they feel very happy and even curious about the story of the movie. Such as, representative answers from participants as follows:

"The feeling is happy and quite curious as to what the continuation of the story behind the short movie will be". (NZL-p1)

Based on the answers above that have been revealed by 3 participants, from the enthusiasm of 2 out of 3 students have a positive response that is enthusiastic in learning vocabulary using short English movies and all participants feel happy and do not feel bored with the various genres of movies they watch. One of them considers that English is a unique language. In addition, that from a movie there are still many interesting genres to watch as a media to learn more vocabulary. 
2086 Students' Perspectives towards English Short Movies as Media to Assist Their Vocabulary Mastery in Online Learning - Irvan Irmanda, Yousef Bani Ahmad, Abdul Kodir Al-Baekani

DOI: https://doi.org/10.31004/edukatif.v3i4.1151

\section{Methods In Learning Vocabulary}

The researcher was also interested in what methods were applied by the participant, what kind of memorization method was applied, and the process of learning vocabulary using English short movies. All participants have different answers regarding the learning process. The first finding from the first participants was that the learning process used was by watching several short movies and then next to them were books and pens to record new and unfamiliar vocabulary expressed by one of the characters in the movie they watched. Then, the words that have been recorded are converted into song lyrics, and are memorized every day by singing. As in the expression below:

"The trick is to watch a few short movies and then, next to it there is a book and a pen to record new and unfamiliar vocabulary" (NZL-p1)

"Well, I usually use this in my daily life, for example, all day long I will say the new vocabulary and make a few words into a song with the vocabulary in it".(NZL-p1)

As can be seen from the above expression, the learning process used by the first participant (NZL) was very effective by writing foreign words by recording from the movie's characters, so that they were easy to remember as song lyrics. Different from the second participant (DSY), she is actually more interested in the genres she watches, the more movies and genres she watches, the more vocabulary she gets. In addition, the memorization process used is quite different from the others these participants remember more the words heard in the movies that have been watched and repeated in school learning. Like the quote below:

“ I guess I'm still looking for something like this, for example, if watching this is fun, okay, I'll watch it again tomorrow, the genre is like this and the language is English, so you'll add your vocabulary later"(DSY-p2)

"If that's the case, I don't remember, but we'll meet later in class. Oh, these words have appeared in this movie where this character said, oh, like this, the pronunciation, so we memorized it again". (DSY-p2)

Furthermore, as we can see from the above expression conveyed by the second participant (DSY) actually has a different principle, the more genres of movies he watches, the more vocabulary he gets. On the other hand, the third participant (YLD) has a method or method that is almost similar to the first participant (NZL), namely watching a movie by using the subtitles in the short movie, then recording vocabulary and translations. In the memorization process (YLD) it was different from the others, this participant chose to make a table with the order of the word classes he got in the short movie, such as verbs, adverbs, nouns, and adjectives. As illustrated below:

"I definitely watch movies with lots of subtitles and sometimes I like, what do I want to say, think about the movie, the vocabulary has been written, I translate it again, I keep repeating it like that"(YLD-p3)

"Usually I have my own book and then write it like that, like it is written or made into a table, like the class of words is arranged". (YLD-p3)

Based on the findings above, the three participants have different learning methods in using English short movies as a media to help their vocabulary. The three differences are that the words that are obtained in the movie are easier to memorize by making a song lyric, the short movie makes them more helpful when there is learning at school that appears is the vocabulary they memorized in the previous English short movie, and how to make tables can help classify the word classes that are obtained in English short movies. 
2087 Students' Perspectives towards English Short Movies as Media to Assist Their Vocabulary Mastery in Online Learning - Irvan Irmanda, Yousef Bani Ahmad, Abdul Kodir Al-Baekani

DOI: https://doi.org/10.31004/edukatif.v3i4.1151

\section{Kinds Of Word Class}

There are many types of word classes in English such as verbs, nouns, adjectives, adverbs, pronouns, prepositions and conjunctions. Therefore, researchers are interested in researching what kind of word classes are used in vocabulary learning using English short movies. It can be used as a new finding to find out how far students learn vocabulary. As expressed by three participants as follows:

"Usually, the words that are usually used are verbs, adverbs, adjective pronouns and nouns, the rest are not very good at it". (NZL-pl)

"There are a lot of word classes, usually I prefer in verbs". (DSY-p2)

"Usually, I prefer verbs or adverbs like that". (YLD-p3)

Based on the answers above expressed by the three participants, when watching the short English movie the word classes they took from the movie were, among others, the first participant (NZL) preferred the word class verbs, adverbs, adjectives, pronouns and nouns, the second participant (DSY) prefers to take a verb while the third participant (YLD) chooses a verb and an adverb. Therefore, it can be concluded that the class of words they mastered in learning vocabulary using English short movies prefers the class of words that are often used such as verb, adverb, noun, pronoun, and adjective.

\section{Kinds Of Movies}

The next point in the subsection of student perspectives examines the types of movies that students use to increase vocabulary. This point relates to the genres that are usually used by students as media to help them in the vocabulary learning process using short movies. It turned out that, from these findings, the three participants tended to choose the cartoon or animation genre in learning vocabulary using English short movies. It can trigger students to be more active in adding vocabulary because some animations or audiovisuals attract students' attention. As quoted from participant representative below:

"There are movies that are like cartoons, there are 15 minutes, 30 minutes, if you don't know about humans, I haven't tried it". (NZL-p1)

In addition, the online media that is used to watch the short movie is by using the YouTube application. Based on the fact expressed by the second participant (DSY) that he prefers to watch movies on the YouTube application where there are various kinds of videos, especially short English movies with the cartoon genre. As the quote below:

"Usually movies from CGI, those on YouTube are cartoons, and prefer to animation”. (DSY-p2)

The statement above shows that the type of movie used is very important for the development of students' vocabulary. The cartoon genre is a genre that is often used by many students as a benchmark for learning more vocabulary. On the other hand, the online learning media used by students is very easy to use, such as YouTube, students can access faster by using the internet. Based on the statement stated above, it can be concluded that the use of English short movies that are often used by students are cartoons and more to fiction or animation. In addition, online media or applications used to access English short movies are YouTube.

\section{The Advantages and Disadvantages of Learning Vocabulary Using English Short Movies.}

Researchers are also interested in knowing the advantages and disadvantages of using English short movies as a media to assist student vocabulary. It was shown from 3 participants who gave statements related to this matter. The first statement expressed by the first participant (NZL) the advantages of short movies are that they are easy to access anywhere and anytime, and not easily bored in watching English short movies, they actually feel entertained by the movies they watch. However, the shortcoming experienced by these 
2088 Students' Perspectives towards English Short Movies as Media to Assist Their Vocabulary Mastery in Online Learning - Irvan Irmanda, Yousef Bani Ahmad, Abdul Kodir Al-Baekani

DOI: https://doi.org/10.31004/edukatif.v3i4.1151

participants was that there was no supervision from a teacher to correct errors in the pronunciation or writing of the vocabulary. This finding is illustrated by the students' words:

"The advantages are that it can be accessed easily using a smartphone or laptop, usually the cost is more affordable... the learning time is also more flexible, the disadvantages are reduced interaction with teachers or instructors and lack of supervision".(NZL-p1)

As we can see from the quote above, it shows that the students find it helpful but lack supervision to check the vocabulary and pronunciation errors they get when watching English short movies in online learning. While the second participant (DSY) revealed that the advantage of using short movies in English is that they are more visually appealing to watch so that they are more enthusiastic in learning vocabulary. As the quote illustrated below:

"The advantage is because it's visual, so we can enjoy the plot while we're at it, but if it's lacking, we don't focus, for example, we're still discussing the previous vocabulary while the plot is already advanced, so we don't enjoy it”. (DSY-p2)

"For the advantages, because this is a short movie, so we are free to choose whatever movie we like, so we enjoy learning it, well if that's the advantages. The disadvantages is this, we learn on our own, so sometimes if it's not on Google, it means it's also difficult, so there's no assistant, no teacher".(YLD-p3)

Furthermore, supported by the statement above from the third student (YLD) she revealed that the advantages of short movies in English as a media to assist vocabulary are that we enjoy the movie more and we are free to choose what movies we like to study. While the drawback is that just like the first participant (NZL) there is no supervision when there are errors in pronunciation or from the vocabulary he is learning.

Based on the statements from the 3 participants above, there were findings related to the advantages of using English short movies as a media to assist them in mastering vocabulary, it received positive responses including, can be accessed easily with a smartphone, more affordable, flexible study time, and free to choose the movie we like. However, the drawback of using English short movies as a media to assist them in mastering vocabulary is that 2 of the participants answered the lack of supervision from the teacher so that there was no correction of the mistakes we got when learning vocabulary using English short movies.

\section{Students' Perspectives Towards English Short Movies To Assist Their Vocabulary Mastery In Online Learning}

Based on the analysis presented above, findings related to students' perspectives on English short movies to assist their vocabulary mastery in online learning. In this case, it shows that the reason students use English short movies as a medium to help master vocabulary is that short movies are liked by many students, of course among teenagers who are in high school. In addition, the audio-visuals obtained from short movies are more interesting than books or dictionaries so that the skill of listening to the vocabulary in short movies helps them. The results of the same study, (Efrizal, 2018) the results found by researchers in each of these studies, we can see that most students are interested in learning English vocabulary through English movies. They have good confidence to express their ideas in learning activities inside and outside the classroom. In addition, the audiovisual in the movie made them interested in watching English short movies most of them claimed to be able to reduce their fear and stiffness to practice English skills, the frequency and percentage of students' vocabulary mastery increased well in each cycle. In addition, English movies can motivate students to be active and have great participation in vocabulary mastery during the teaching and learning process in the classroom.

Furthermore, revealed that watching short movies in English helped them in mastering vocabulary, especially in terms of affective, students felt happy and enjoyed a movie that was used as media for them to learn. In addition, students' enthusiasm in using movies was very positive for their vocabulary mastery. This 
2089 Students' Perspectives towards English Short Movies as Media to Assist Their Vocabulary Mastery in Online Learning - Irvan Irmanda, Yousef Bani Ahmad, Abdul Kodir Al-Baekani

DOI: https://doi.org/10.31004/edukatif.v3i4.1151

condition is similar to the research conducted by (Aditama \& Solikhah, 2018) which revealed that students were more active in practicing the material using short movies than before. Short movies can help students be more confident in mastering vocabulary. During the teaching and learning process using short movies, students showed that they were more active and enthusiastic in learning English. Using short movies is very effective in teaching and improving vocabulary mastery. Students not only improve their vocabulary but also understand the plot in the movie story. Students know the meaning of words. Students also know about multiple meanings, and how to place words according to their context.

The same result is proved by (Sadiku, 2018), Learning new vocabulary, as a demanding task most language learners play an important role in language learning and especially in improving their communication skills. On the other hand, the improvement in terms of skills is where the vocabulary collected in the notes is turned into a song lyric by arranging words that have been written previously. It demonstrates students' skills in creative teaching methods. On the other hand, access to multimedia resources and various technologies, including subtitled movies, offers students many opportunities to enrich their vocabulary. The value of subtitles in helping students through the vocabulary acquisition process has been seen by many scholars. Thus, many studies have been conducted to explore the effectiveness of watching movies with subtitles in vocabulary acquisition. Therefore, the findings of this study related to the methods used are almost similar to previous studies. it illustrates that the three participants have different learning methods in using English short movies as a medium to help their vocabulary. The three differences are the words obtained in the movie are easier to memorize by making song lyrics, short movies make them more helpful when there is learning at school that appears is the vocabulary they memorized in previous English short movies, and how to make tables can help to classify the class of words obtained in English short movies.

Furthermore, according to (Vitasmoro, P., Chandra, A. I., \& Jatmiko, 2019) their research related to improving student's English vocabulary mastery through animation cartoons. This study has shown that increasing students' vocabulary on the use of cartoon movies is very effective and helps students. This finding implies that research makes mastery students' vocabulary increased significantly more vocabulary than before, students memorize new words more easily and students are more confident than before. Animated cartoons are a technique used to help students learn vocabulary and can be used to solve students' problems in learning vocabulary. In addition, the word class in short movies with the cartoon genre found that the word classes that appear more often including, verb, adverb, adjective, noun, and pronoun. Animated cartoons not only help students in learning English vocabulary but also help teachers create interesting techniques. Therefore, this study shows that students are more interested in using short movies with the cartoon genre on the grounds that short movies with the cartoon genre are more interesting and fun. Besides that, it can eliminate boredom when learning vocabulary.

(Simpuruh, 2021) consider that the movement used in teaching English vocabulary achievement has proven to be more effective in improving students' vocabulary achievement and students' interest in learning English vocabulary. However, this researcher would like to suggest that the supervision of an English teacher is important to manage materials and classes for teaching English vocabulary. Therefore, this motivation will indirectly be interested in learning English vocabulary. If they are interested in the subject, they will concentrate more and get success. This study also states that supervision, when students do online learning, is very lacking, especially in focusing on ongoing learning. Similar to this study, that the statements of the 3 participants above, there are findings related to the advantages of using English short movies as a medium to help them in mastering vocabulary, receiving positive responses including, being easily accessible with smartphones, more affordable, flexible in learning time, and are free to choose the movies we like. However, the drawback of using English short movies as a medium to help them in mastering vocabulary is that 2 participants answered the lack of supervision from the teacher so that there was no correction for the mistakes we got when learning vocabulary using English short movies. 
2090 Students' Perspectives towards English Short Movies as Media to Assist Their Vocabulary Mastery in Online Learning - Irvan Irmanda, Yousef Bani Ahmad, Abdul Kodir Al-Baekani

DOI: https://doi.org/10.31004/edukatif.v3i4.1151

\section{CONCLUSION}

The findings of this study were found from three students of SMAN 2 Telukjambe Timur Karawang as respondents who gave their experiences in using English short movies as a medium to help their vocabulary mastery. Based on research findings and discussion that Students have expressed positive perspectives of the use of short movies as media used in online learning in the above disclosures, including reasons, affective, methods, kinds of word class, kinds of movies, and advantages and disadvantages. On the findings above, that most students expressed positive responses to the use of English short movies as media to assist them in mastering vocabulary, students were felt happy, entertained by the animated movies they watched, the online media used were quite easy to access, it supports the metacognitive development of students. however, on the other hand, that the use of short movies does not always run smoothly, sometimes students find difficulties in the pronunciation spoken by the characters in the movie, therefore students need the supervision of the learning process as it progresses. Following the purpose of this study, to know students' perspectives towards English short movies as media to assist their vocabulary mastery in online learning.

\section{REFERENCES}

Aditama, A. P., \& Solikhah, I. (2018). The Implementation of English Short Movie to Improve Students' Vocabulary Mastery at the First Grade Students of SMA $N 8$ Surakarta in the Academic Year of 2017/2018 (Classroom Action Research). STATE ISLAMIC INSTITUTE.

Baratta, A., \& Jones, S. (2008). (2008). Using film to introduce and develop academic writing skills among UK undergraduate students. The Journal of Educational Enquiry, 8(2).

bin Tahir, S. Z. (2012). Teaching English as World Language: Pengajaran Bahasa Inggris. Media Pustaka Qalam.

Braun, V., \& Clarke, V. (2006). Using thematic analysis in psychology. Qualitative Research in Psychology, 3(2), 77-101.

Efrizal, D. (2018). Improving Students' Vocabulary Mastery Through English Movie for Second Year Students at MAN 01 Kota Bengkulu. Al-Lughah: Jurnal Bahasa, 7(1), 46-57.

Etemadi, A. (2012). Effects of bimodal subtitling of English movies on content comprehension and vocabulary recognition. International Journal of English Linguistics, 2(1), 239.

Ivone, F. M. (2005). Teaching English as a foreign language in Indonesia: The urge to improve classroom vocabulary instruction. TEFLIN Journal, 16(2), 195-208.

Kabooha, R. H. (2016). Using Movies in EFL Classrooms: A Study Conducted at the English Language Institute (ELI), King Abdul-Aziz University. English Language Teaching, 9(3), 248-267.

Khan, A. (2015). Using films in the ESL classroom to improve communication skills of non-native learners. ELT Voices, 5(4), 46-52.

Lail, H. (2019). The Effectiveness of Using English Movie With English Subtittles in Teaching Vocabulary at The Eighth Year Students of SMPN 1selong in The Academic Year of 2018/2019. Journal of Languages and Language Teaching, 6(2), 100-107.

Lestari, R. C. (2016). The Use of English Subtitle in Movie to Improve Students'vocabulary: An Experimental Study In Grade IX Of SMPN 1 Gunungsari. Universitas Mataram.

Lin, J., Wang, A., \& Du, W. (2013). Learning English vocabulary in the Chinese context. International Journal of Language Teaching and Research, 2(1), 4-11.

Patahuddin, P., Syawal, S., \& Bin-Tahir, S. Z. (2017). Investigating Indonesian EFL learners' learning and acquiring English vocabulary. International Journal of English Linguistics, 7(4), 128.

Sadiku, A. (2018). The Role of Subtitled Movies on Students' Vocabulary Development. Int. J. Sci. Basic 
2091 Students' Perspectives towards English Short Movies as Media to Assist Their Vocabulary Mastery in Online Learning - Irvan Irmanda, Yousef Bani Ahmad, Abdul Kodir Al-Baekani

DOI: https://doi.org/10.31004/edukatif.v3i4.1151

Appl. Res, 42, 212-221.

Sarani, A., \& Shirzaei, H. (2016). A comparative study of vocabulary learning strategies employed by Iranian undergraduate and postgraduate EFL learners with a focus on motivation. Indonesian Journal of EFL and Lingusitics, 1(1), 33-45.

Simpuruh, I. (2021). The Use of Gesture in Improving Students' Vocabulary Mastery in Selected Indonesian Junior High School. Utamax: Journal of Ultimate Research and Trends in Education, 3(1), 9-13.

Vitasmoro, P., Chandra, A. I., \& Jatmiko, J. (2019). Improving Student's English Vocabulary Mastery through Animation Cartoon. 363, 505-509.

Wafi, N. M. (2013). The Effectiveness of Using Animated Pictures Program in Learning English Vocabulary among the Fifth Graders in Gaza. 